This is the pre-copyedited author's final version of the journal article accepted for publication following peer review.

Original citation:

Pfeilstetter, R. 2020. Doing good and selling goods. Hybrid Commodities in the Social Enterprise Ecosystem. VOLUNTAS International Journal of Voluntary and Nonprofit Organizations 31 (3): 511-520.

The version of record is available online at:

https://doi.org/10.1007/s11266-020-00194-w

\title{
Doing Good and Selling Goods
}

\section{Hybrid Commodities in the Social Enterprise Ecosystem \\ Richard Pfeilstetter}

\begin{abstract}
This paper explores a network of organizations and their perspectives on the social enterprise commodity. Based on ethnographic research, I present the case of recycled bags sold in the city centre of Vienna (Austria) by three organizations, including a work integration social enterprise. By reviewing two different strands in the organizational studies literature that both employ biological notions to theorize (social) enterprising, I argue that opposing "hybridity" to "ecosystems" is a suitable way to assess two different research agendas in that field. While I subscribe to the ecosystem focus seeing organizations as a function of the social environment - I make the case for the importance of research into "hybrid commodities" as a way to explore larger issues concerning social enterprise scholarship, such as mission drift, hidden agendas or organizational identity work.
\end{abstract}

Key words: hybrid organizations; entrepreneurial ecosystems; social enterprise; commodities; Austria; Spain 


\section{Introduction}

Social enterprise is predominantly used to describe organizations that pursue social goals by means of the market (Kerlin 2009; Martin and Osberg 2007). In turn, hybrid organizations are those that combine two different institutional logics (Doherty, Haugh and Lyon 2014: 418). Because social enterprises combine welfare with profit, they are sometimes held as the ideal type of hybrid organization (Battilana and Lee 2014). In this paper I will present an organization that might be labelled as hybrid. PAPE is a work integration social enterprise giving work opportunities for people with a former drug dependency. For this contribution, I will look at a specific good sold by PAPE to generate income supporting their social mission, namely recycled handbags. This focus on the hybridity of organizations is illustrated in our specific case of PAPE by the combination of "doing good and selling goods". Portraying PAPE as a hybrid organization is a way of exploring similarities of organizational features across time and contexts of social enterprises.

Nevertheless, the meaning of social enterprise varies according to context, whether economic, political, historical, geographical or cultural (Teasdale et al. 2013; Kerlin 2013). In Europe, the rise of social enterprise is related to the withdrawal or decline of the State as social service deliverer (Kerlin 2010: 167; Defourny 2010). Also the shift to liberal policies witnessed in Europe since the 1980s, coupled with the subsequent emergence of a complementary or superior social service deliverer, are often mentioned as a principal cause of social enterprising (Hustinx and De Waele 2015; Molina et al. 2018). In order to explore differences between different contexts within Europe, social enterprise has been more recently described in terms of ecosystems (Biggeri et al. 2017), a view also supported by major institutions such as the European Commission (2015) and the OECD (2016). The focus on ecosystems is often used to account for historically evolved institutions and policies at the national or the state level, for example in discussions over the specificities of social enterprises in Scotland or the UK (Hazenberg et al. 2016a 2016b; Roy et al. 2015). However, the circulation of social enterprise commodities within local ecosystems has received less attention in the literature. Even when scholars look at specific social products, such as for instance food for the poor, it is commercial activity as opposed to donations that constitutes the main focus of attention (Hustinx and De Waele 2015). The products sold by the hybrid organizations I have analysed for this contribution are placed within a urban-national 
ecosystem. The Austrian welfare state - similar to the German - is a system that benefits large public or publically funded welfare corporations (Esping-Andersen 2001: 111114). Public social spending is high in a context of widespread economic prosperity, particularly in Vienna, a city famous for the 100-year old public housing policy, that has been governed by the social democrats for decades. These contextual factors explain much of PAPE's evolution, problems, workings and achievements. From this ecosystem angle, social enterprising in Vienna, Austria and elsewhere is a context dependent phenomenon.

Summarizing, ecosystem and hybridity are two different, but also widely employed abstractions to make sense of social enterprising. Discussing some of the literature on both concepts, I argue that viewing social enterprises as hybrids a priori assumes a conflict between two categories and frames these in universalizing terms, such as for example altruism versus self-interest. In contrast, viewing these organizations as a function of an ecosystem directs the gaze towards local negotiations over the meaning of - for instance - doing good or selling goods. Hybridity would thus stand for a universal, synchronic organizational feature. In opposition, the ecosystem is expressing a historically particular Zeitgeist of specific organizational networks. I further show how both positions are often closely related to the methodological framework underpinning research. Formal or isolated case studies on the one hand and long-term, in-depth field research on the other. These give way to two different understandings of social enterprise. This paper is based on three years of close collaboration with social enterprises in Seville, Glasgow and Vienna and particularly on the data generated during two months of immersive field research at PAPE. Therefore, the ecosystem viewpoint on embeddedness of social enterprise is more compatible with my field experience.

Nevertheless, I will use the notion of hybridity to conceptualize the different meanings that the social enterprise commodity conveys within the Viennese ecosystem. I will show how PAPE and their competitors express different perceptions and arguments over the social, ecological or commercial nature of handbags they sell. Within the ecosystem literature, less attention has been paid to the products sold within the system and their symbolism. In order to address this gap, in this contribution I explore the specific meanings of particular products within a local market. I ask to what extent the moral grammars associated both locally and situationally with certain objects may 
undermine or enhance the perception of enterprises as "social" or "hybrid". In this respect, the focus on the ecosystem seems highly relevant, because apparently unproblematic and intrinsically "social" or "ecological" items sold by social enterprises may acquire entirely different connotations within the confined social spaces in which these are judged, bought and sold. I therefore oppose the synchronic view on fair-trade, hand-made or local products as "hybrids" supposedly halfway between conventional goods and donations. Instead, my case from the Viennese ecosystem aims to show how bags that are recycled and handmade by excluded persons, can nevertheless get associated with negative value judgements like greediness, imitation, unfair competition or loss of identity. It is to this extent that I address the question of hybrid commodities in the social enterprise ecosystem.

The paper proceeds as follows. First, I discuss two different views on social enterprise by comparing the literature on hybrid organization to that of entrepreneurial ecosystems. I situate my research interest on local social enterprise contexts broadly within ecosystem literature. Within this field I identify the gap regarding the local value attributions to social enterprise commodities. In the following methodology section, I show how my immersion with the local contexts of PAPE evolved. I also discuss the extent to which my participatory research approach reflects issues about the researcher's role, a matter of much debate in the recent literature on ethnographies of social enterprise. What follows is an ethnographic account of discourses, practices and places associated with a social enterprise commodity, recycled bags in Vienna. In the discussion section I dissect this empirical material by asking how these goods speak of the larger issues identified in the social enterprise literature on hybridity. This includes problems such as mission drift, unfair competition, ambivalent identities or hidden agendas. In the conclusions, I make a case for the interest that research into the polysemic or hybrid object traded by social enterprise has for this field of research.

\section{Social enterprise: hybridity and ecosystems}

The ever growing global and diverse "social enterprise zoo" (Young et al. 2017) has led to a vast and heterogeneous field of research over recent years. In this contribution, I suggest that one way of getting to grips with the diversity of scholarship is to focus on two different biological analogies frequently employed to theorize (social) enterprising, namely hybridity and ecosystems. Bringing together both concepts that are normally 
employed in different forums (with a few exceptions, such as Roundy 2017a; 2017b; Mcmullen 2018) allows us to illustrate two major conflicting paradigms in social enterprise research. While subscribing to the "ecosystem" focus on embeddedness, I will defend the need for more research into the local meanings of ambivalent or "hybrid" social enterprise commodities.

The metaphor of hybridity is used in the social sciences to refer to mixing of social categories or logics. Frenkel and Shenhav for instance describe the field of management studies as a hybrid of practices and texts from both the colonies and the metropoles (2006). Engaging with hybridity as a concept is a theoretical endeavour that requires the previous acceptance of a small number of Weberian ideal types (Billis 2010). For instance, in order to frame a field of research or an organization as a "hybrid", two simplified social variables need to be constructed beforehand, such as for instance the colonizers versus the colonized or the public versus the private. This cornerstone or epistemological blind-spot of the concept makes research on hybrid organizations an utterly deductive endeavour. Based on a taken for granted assumption of two or more universal synchronic variables - typically profit versus philanthropy (Battilana and Lee 2014) - researchers then reach out to explore the relationship between these opposite logics in practice. As a result, some focus on the desirability of a balance between the variables. They look for empirical evidence on how "mission drift" in one or another direction is avoided or what mitigating strategies are implemented by practitioners to maintain balance (Cornforth 2014; Raišienè and Urmanavičienè 2017; Gidron 2017). Others are concerned with the locus of both logics within organizations, such as Ebrahim et al. (2014) who differentiate between "differentiated hybrids" who engage in two separate activities (welfare delivery here and trading there) as opposed to those who truly combine both variables. In the latter case trading is the welfare delivery, for instance to a vulnerable customer or to a vulnerable employee. A similar distinction is that of hybridity at the "core" (social enterprise) or at the "periphery" (corporate social responsibility) suggested by an influential paper by Battilana and Lee (2014). Summarizing, I would like to argue that a focus on the hybrid nature of social enterprise tends to nudge research towards a top-down enquiry driven by ideal type social categories, or in other words, a preferential interest in formal organizational features as opposed to historical or geographical particularities. This is instead the focus of most writing using the term "ecosystem". 
As Roy and Grant have discussed recently (2019), the notion of substantive economy as conceived by Karl Polanyi (1944), is opposed to the "social - economic dyadic" typical of some of the social enterprise scholarship on "hybridity". Following Polanyi, the economy is part of the society. For him the idea of two different spheres is misleading, because social life is a totality assembling morality, kinship, politics, environmental constraints, law, and biological adaption, among others. As I will show in the following, this "totality" is increasingly called "ecosystem" in recent social enterprise scholarship. The ecosystem relates to place and proximity. These are among the most important variables to understand entrepreneurship (Brown and Mason 2017). The example of Silicon Valley is for many the living proof (Cohen 2006). Literature on entrepreneurial ecosystems has grown importantly since the 2000s (Motoyama and Knowlton 2016), with an exponential increase since 2010 (Alvedalen and Boschma 2017). The basic assumption is that a network of actors within a confined social space is responsible for business innovation (Cohen 2006). This reminds of the much elder notion of "embeddedness", this is the idea that the economy is part of (and not detached from) social relationships (Granovetter 1985). Such a focus on "the system" or the "totality" directs the analytical gaze to interdependency, the environment and adaptation. Importantly, it directs the attention away from the parts the make up the system, such as the hybrid organizations on their own terms. This ecosystem concept has more recently expanded from the mainstream business literature to the niche of social enterprise scholarship (Biggeri et al. 2017a; 2017b; Roy et al 2015; Hazenberg et al. 2016a; 2016b; Roy and Hazenberg 2019; Roundy 2017a; 2017b; Thomsen 2018; Littlewood 2018). I will discuss some of this literature in what follows.

In a recent policy brief, Biggeri et al. (2017a) serve the recent political agenda of supporting social enterprise and the related promotional slogan "enabling ecosystems" (European Commission 2015; OECD 2016). These academics and institutions focus on socio-entrepreneurial ecosystems as something inherently positive to be supported by policy makers, for instance by reducing "legal constraints" and increasing funds, publicity and training for the sector (Biggeri et al. 2017a: 301). A quite different strand in the literature equates the ecosystem with the specific nations or states under study, for instance in the often cited case of Scotland (Roy et al 2015; Hazenberg et al. 2016a). In these cases the ecosystem is an umbrella to describe a national social history, specific cultures or values of "the people" and government politics of one nation as opposed to 
another. For instance, Roy et al. associate the particularities of the Scottish ecosystem with the history of worker cooperatives, the labour movement and enlightenment thinkers, together with "natural inclinations" of Scots towards socio-democratic values (as opposed to England), and a strong government support for social enterprise (2015: 781-784, 795). Using a similar historical and nation-state centred framework, but giving the biological analogy that comes with the ecosystem concept a chance, Hazenberg et al. distinguish between two different ecosystems. Scotland and England are portrayed as two different "phenotypes" (community grant-based versus individualistic credit-based) but also marked by similar genetic (UK social history) and epigenetic (EU policies) factors (Hazenberg et al. 2016a: 215-217). Building on this contribution and adopting the language of Pierre Bourdieu, Roy and Hazenberg compare the ecosystem with a rule-based social field, structured by power relations and with actors employing social, cultural and economic capital to improve their position in the field (2019). Roundy (2017b) is interested in the interplay between social enterprises and the larger entrepreneurial ecosystem. The ecosystem here is that of the business world more generally and social enterprises are seen as parts that both affect and are affected from the system. For instance, a philanthropic culture within a business ecosystem may give birth or support to social enterprises. Social entrepreneurs improve the quality of life of the ecosystem and thus make it more attractive to ordinary business too (Roundy 2017b: 11-12, 15-16). Yet another different take on social enterprise ecosystems may be illustrated with a work from Thomsen et al. who look at a more specific context, namely Universities (2018). Here the ecosystem is a specific bound institutional environment with particular resources. These "university based" ecosystems consist of student engagement, social responsibility or applied learning, coupled with specific limitations, such as disciplinary boundaries, lack of expertise or funding (2018: 199, 207, 209).

Summarizing, I have shown that the popular theoretical focus on social enterprises as "hybrids" comes with a series of implications, most importantly its focus on conflicting ideal type features of organizations. In contrast, I have shown that the ecosystem literature focuses primarily on networks of actors (Cohen 2006; Littlewood and Khan 2018), on historically evolved institutions and policies (Roy et al. 2015) and often matches ecosystem with the national or state level (Hazenberg et al. 2016a; 2016b: 302). My qualitative methodology and the case study that I will present in the following relates to this literature in three different ways. First, my research was embedded in a 
larger project's emphasis on the local and national particularities of social enterprises. I learnt about these particularities through long-term field visits to specific organizations such as PAPE. Therefore, I found in the ecosystem (as opposed to hybrid organizations) a suitable language to describe my empirical material. Second, my case focuses on the present-day circulation of commodities in the relatively small area of inner-city Vienna. In this sense, my case of the contemporary Viennese social market of recycled handbags addresses several understudied dimensions within the ecosystem literature. I look primarily at objects not actors and at an urban district not a country. I tell a contemporary ethnographic story and don't give a historical account of national welfare traditions. Thirdly, I apply the concept of hybridity to make sense of the ambivalent meanings that my informants attach to the social enterprise commodity. By leaving the definition of the conflicting categories constituting "hybridity" to the actors of a confined social space, I show a way to make this concept operational from an "ecosystems" point of view. In the following section I show the ways in which I have investigated this hybrid commodity within a specific ecosystem. Specifically, I discuss the challenges of my qualitative case study research design.

\section{Methodology: ethnographies of social enterprise}

There is growing use of ethnographic methods in social enterprise research (Hill O’Connor and Baker 2017: 180; Mauksch 2016; Mauksch et al. 2017). Central concerns of ethnographers include thinking about our roles as researchers, assessing our moral and political commitments in relation to the people we work with, and reflecting on our writing, particularly regarding its accuracy in describing the specific social conditions in which our data was produced (Clifford and Marcus 1986; Marcus 2001; Gilmore and Kenny 2015). In the following, I will first describe with some ethnographic detail how my research with PAPE evolved over time, what kind of positions I occupied in the field, the specific interview and observational techniques I applied and their effects on the data produced. More generally, I want to expose the overall circumstantial history of how I got drawn towards the subject of the social enterprise commodity in the Viennese context. In the second part of this section, I will then turn back to discuss some of the before mentioned methodological issues of participatory research in relation to my engagement with PAPE and the Viennese ecosystem more broadly. 
In 2016 I went to Vienna to investigate PAPE during a two month research field trip. My visit was supported by a program that funded international exchanges between a total of 28 universities and social enterprises from 17 countries worldwide. The project aimed at investigating social enterprises comparatively by bringing together practitioners and researchers. In my case, this entailed a total of 6 months of observational visits to Glasgow, Berlin, and Vienna, receiving practitioners from Israel, Argentina and Italy at my university, and collaborating closely with a local social enterprise in research and teaching. During the project period between 2016 and 2018, I have produced many hours of recorded and unrecorded interviews, field notes and research reports on national and local social enterprise ecosystems. For this paper, I have selected the Viennese experience from my material as a particularly illustrative example of the importance to understand the social enterprise commodity. All the names of persons and small-scale organizations mentioned throughout the paper are anonymized.

I was received in Vienna by Valerie at PAPE who was responsible for the organization's participation in the project. PAPE had committed itself to hosting visiting researchers like me in exchange for the opportunity to receive funding for their staff to visit academic organizations. Valerie was responsible for the shop management and we met several times at PAPE's shop in the city centre and at the workshop in a less affluent quarter. It was there that Valerie explained to me the workings of PAPE and her views on the third sector in Vienna, but I also had the opportunity to occasionally talk to other employees and customers. I took notes after all of these conversations and documented my impressions during my visits. Valerie also arranged a meeting with Gina, the charismatic founder of PAPE. I recorded and later transcribed and translated the interview. Some of my days in Vienna, I spent writing up my field notes and reading about the Viennese ecosystem at the local University of Economics. Introduced by one of our project academic partners who was based there, I got to know other researchers working on the social enterprise ecosystem in Vienna. Among others, these included three researchers who were working on a sophisticated model to quantify the social impact of PAPE. We agreed to meet for a group discussion to exchange our data and impressions concerning PAPE. I later also had access to the extensive research report that they had written, together with many other documents available on the internet on what was a fairly successful and media-effective organization. Once I got acquainted 
with PAPE, I became interested in their main commodity and noticed other shops that sold the same or similar items. I visited Freitag, a large international corporation selling recycled fashionable bags, Caritas, a large international welfare corporation selling recycled fashionable bags, and 48-er Tandler, part of the large public waste management company of Vienna, also selling recycled fashionable items. I researched this ecosystem of products and organizations located close to each other in the Viennese city centre, as I did with PAPE before, shooting photos, having informal conversations with staff and costumers, and writing the information down after my visits. Taken together, the case of the social enterprise commodity presented in the next section, rests on the empirical material gathered from an immersive multi-sited qualitative study.

Gaining rapport, or the establishment of good personal relationships with our informants, is often seen as a crucial precondition for producing reliable and truly ethnographic or qualitative data (Sherif 2001; Mazzei and O’Brien 2009; Gajparia 2017). Nevertheless, rapport has also been associated with a very technicalopportunistic approach to research with humans. For instance, the positivistic aims of rapport have been described as a "covering shorthand" for all the factual contingencies during fieldwork, whilst collaboration or complicity have been suggested instead as more accurate ideals for the fieldworker (Marcus 2001: 520). When describing my position as researcher in relation to my informants in Vienna previously, it might be argued that I moved somewhere between these two extremes. In spite of working as an anthropologist at a Spanish University, I was a native German speaker to my Austrian informants and could also present myself as a trained social worker, having worked for or with work integration social enterprises before my academic career. In addition, I was technically a direct partner of PAPE in the context of a research project. I would like to argue that this was enough common ground for substantial, meaningful and open conversations. For instance, talking about our private family circumstances during interviews or the personal relationships with other professionals from the Viennese social enterprise ecosystem could be seen as indicators of a certain amount of trust established with the academics and professionals I talked to. Nevertheless the promise of "complicity" as a way of erasing the subject-object relation in participatory research would be an exaggerated presentation of my field work. Among others, a particularly graphic example of the limits to rapport within my research might be my requests to sign interview consent forms and to ask for permission to record interviews. Both are 
often indicators of major obstacles to the aspiration of doing research in a representative, ordinary social environment (see Nordstrom 2015). This discussion of the conditions, constraints and possibilities of my research in Vienna shall justify the extent to which the case study presented in the following section can be used to generalize about the social enterprise commodity at the end of this paper.

\section{The Viennese ecosystem for recycled bags}

When I first went to visit PAPE back in 2016, I was looking for the kind of work integration social enterprise I was acquainted with as a social worker in the German context. This is often a large functional and slightly out-dated fabric building out of town adapted to the special needs of vulnerable groups to do manual labour. However, on my way to PAPE, I found myself in one of the most exclusive quarters of inner-city Vienna, in a street with several shops selling or exhibiting art-design items, where PAPE was one among others. I was received by Valerie, the shop manager with a background in public relations, who in response to my astonishment told me that most people knew PAPE for their price-winning design products and not for doing "something social". Gina, the chairwomen and founder, explained the importance of the goods PAPE sold as follows.

They come here because they know the products. Many don't know that we have a social background. Not at all. In the meantime we are in all kinds of tourist guides, as I say, from Taiwan to New York, and there it does not say [work integration social enterprise], there it says design shop.

I would later visit PAPE's workshop, which largely fitted my previous description of ordinary work integration social enterprise facilities as I knew them. Nevertheless, after a few more visits to the "popup store" in the city centre, I became aware that this place with its "design products" represented how this organization was seen and how it wanted to be seen. Particularly, among the first and most selling flagship items prominently showcased in the shop were bags made of old truck canvas. In what follows, I want to focus my narrative on this specific identity-building social enterprise commodity and the manifold discursive and physical sites where I encountered it during my fieldwork.

Since its foundation in 2002, the organization relied on specific bags as a commodity that had a market, that was feasible to be assembled by their temporary employees and 
fitted with the ecological design idea that Gina had in mind when starting the enterprise. The bags were suitable as a "social" work integration activity for people overcoming their drug dependency, because sewing could be learned and was a meaningful task to accomplish, especially since the end-product could be exhibited and therefore also cherished. The recycled canvas raw material also contributed a green image to the organization, and the different imprints it provided ensured that every item had a unique design. Finally, the goods were a viable business product because they were made extremely popular by a large multinational Austrian brand called Freitag. As Gina recalled

At that time [during the foundational period of PAPE] we benefited from the fact the Freitag brothers just started with these Freitag bags and we said we will never make bags because already someone else is doing that...

But they did; a fact that would force Gina to come back to defend repeatedly the differences between Freitag and PAPE during our interview.

We have decided very consciously for quality. Very clearly we work as a classic design workshop, everything handmade, not like the Freitag bags that are made mechanically. That's all handmade.

Because both organizations produced exactly the same specific item, and PAPE had probably copied the famous Freitag product, it was the distinction between the mechanically produced bulk commodities as opposed to the handmade "quality" product that was the main argument to differentiate "ordinary" enterprising from "social" enterprising. Nevertheless, there were additional arguments about why the same commodity sold by PAPE was different to those of others.

\footnotetext{
Yes, I understand that people who are poor go to HandM or KiK or somewhere else. Why? Because the production is cheap. If this isn't changed in Europe, we are exactly there. Because then people come to us and say: "At your place a handbag or bag pack costs 140 Euros, but you are a social project, aren't you?" Then I say: “No, we are a business, we pay 14 salaries a year. Normal wages. 14 times a year.” At Freitag you also pay 185 Euros and it is done mechanically. There is no human sitting there and sews this with the hand. [...] You can really see people working [at PAPE] and it is not alienated somewhere.
}

Here two additional arguments come to the fore. PAPE is posited by Gina between the large textile multi nationals (HandM, KiK, Freitag) producing either cheap or mechanically and outside Europe ("alienated somewhere") and the welfare organization 
("the social project") that does not have to earn salaries for their employees by trading successfully. This struggle over the interpretation of the bags seemed to be an important issue for this social enterprise, especially regarding how they explained their mission to outsiders like me. The reference to the "ecosystem" was made in terms of other organizations viewed as illegitimate competitors, while selling similar items. This made me aware of the importance to focus on both the ecosystem of organizations and the ways in which a commodity was theorised as "hybrid" by my informants. Different elements assembled the meaning of the product: price, site of production, size of the company, whether salaries were paid or not.

Therefore, I went to visit the network of organizations selling the same product in approximately two kilometres distance from each other in the centre of Vienna. Apart from Freitag who had made these kinds of bags popular since the 1990s, there was also Caritas, who sold similar bags as part of a work integration project for young people with education deficits. At Caritas the bags were sold in a less glamourous area of Vienna and in the same premises as the workshop. The opening hours were restricted (not commercial) and the bags were also sold at a much cheaper price (thus subsidized). People here received a "pocket money", not a salary as in the case of PAPE. Therefore in the Caritas shop the work integration dimension was displayed much more prominently. While the people who made the bags were on display physically and through advertising in the case of Caritas, the opposite was the case in the Freitag shop. Their "flagship store" was located in the main shopping area, in the neighbourhood of other textile multinationals. Here the commodity itself was exhibited and celebrated in a nearly museum-like atmosphere. The bags were showcased as an utterly extraordinary design item, a fact that was underlined with a price that exceeded those of PAPE and Caritas by far.

\section{Discussion: the importance of the social enterprise commodity}

What these interviews, notes and field observations show is that the products sold by PAPE were central to the possibility to self-identify occasionally as hybrid organizations, half-way between business and welfare. While economic reliance on their sales was small because PAPE financed about $20 \%$ of their budget by the means of the market, these products added the possibility of showcasing a socio-entrepreneurial angle to a design shop that primarily depended on public funding (more than $70 \%$ ). It was 
more that the products themselves (and not their sales) represented the core ideology of social enterprise. The bags were hand-made by former drug users and from recycled materials. These commodities aimed to show that "doing good and selling goods" could go together, which did not necessarily mean that it was a successful way to sustain the financial needs of a protected workplace for vulnerable people.

Nevertheless, it seemed that the bags also symbolically stood for the threat of mission drift (Cornforth 2014; Ebrahim et al. 2014) or the suspicion of hidden agendas (Dey and Teasdale 2016) that could be raised by outsiders, such as me as an academic visitor. This impression had to be avoided, for instance when Gina was justifying emotionally the elevated prices of their handbags as compared to similar ones from the corporate sector. The prices should not be seen as an expression of an illegitimate greed for money, but as an added social value of products being handmade. Nevertheless, at a different moment of the interview, Gina's comments implied that they had probably copied the innovative product from a corporate competitor. They were capitalizing on the market that this international brand had created previously for this particular product among the affluent Viennese city-centre shoppers. This led the founder to convey the opposite argument, namely that they were not a charity and had to provide wages for work that should be duly paid. Here was an attempt to avoid the potentially opposite perception of PAPE as an ordinary charity organization. From the inside perspective of the ecosystem, this organizational type was represented by a large welfare corporation such as Caritas. They only paid "educational pocket money" not wages. In this case, the commodity was only a means to an end, not a high-end design item. It is to this extent that the "ecosystem" - in our case the relationship between Freitag, Caritas and PAPE in regards to recycled canvas bags - defines the meaning and workings of social enterprise in Vienna.

With regards to the bags as a specific "socio-entrepreneurial" commodity within an ecosystem, I have shown that three competitors were part of a microcosm for recycled design-products in the wealthy city centre of Vienna. In this social context, as our example of the canvas bags illustrates, PAPE is confronted with multinational corporations that produce and sell the same commodity. Freitag, with an approximate revenue of thirty million Swiss francs, lacks the social mission of PAPE, but trades as an ordinary business in the field of sustainable life-style products. The Austrian offshoot of Caritas has close to fifteen thousand employees and a budget verging on eight 
hundred million Euros (Caritas Austria 2016). Mainly funded by the state and the church, Caritas also sells recycled handmade handbags made of truck canvas by vulnerable people. In comparison, PAPE had thirteen full time employees. In PAPE's rhetoric and scenography aimed at putting their products in a different light to those of their neighbours, scale was therefore an important dimension. Others could be blamed directly or indirectly for producing abroad, using machines or of operating independently from sales. In this respect, social enterprises as a kind of "petty capitalist" can count on a leap of faith from the public in comparison to corporations (Blim 2005).

Summarizing, several threats and potentials for the identity and reputation work that social enterprises do (Teasdale 2010) can be attributed to values associated locally to certain commodities. First, products that are expensive and exclusive may be seen as inadequate for a welfare organization that is expected to offer affordable and inclusive products. Here the presence of similar commodities in the ecosystem can work as a resource that allows social enterprise to distribute the liability of elevated prices by contrasting their workings to those of others. Second, similar products sold by other organizations in the ecosystem may raise suspicion over unfair competition or undermine the innovative image of social entrepreneurship. Here the reference to the business angle seems to be the way in which social enterprises confront other traders in the ecosystem. Especially work integration providing "real" wages as opposed to more symbolic or donation-like pricing offered within the ecosystem is the way in which social enterprise mitigates this threat. Thirdly, similar objects sold by organizations from the corporate and welfare sectors can undermine the perception of distinctiveness of social enterprise altogether. In this respect, it seems that the size of organizations (a perception that is strongly influenced by the ecosystem) is a way of diluting the threat that social enterprise commodities pose to the preservation of distinctiveness of "hybrid" organizations.

\section{Conclusions}

In the muddled terrain of corporate social responsibility, green business and marketized social welfare, "social enterprises" increasingly struggle to justify the uniqueness of their position as commercial social service organizations. In my case from Vienna, we have seen how a work integration social enterprise explained its difference compared to 
a corporation and a traditional large-scale welfare provider. I illustrated this by telling an ethnographic story about one specific product sold by these three different types of organizations. While all of them seemed to embrace the double ideal of doing good by selling recycled goods, they did so by different means: mechanical production abroad in the case of the corporation, manual voluntary work in the case of the traditional welfare organization, and manual salaried work in the case of the social enterprise. From PAPE's point of view, this was the crucial difference. Nevertheless, this was not evident to costumers or outsiders like me. This brought the social enterprise in a position where the distinction of an apparently similar product had to be thoroughly explained and justified.

I showed that the notion of "hybridity" in the organization studies literature helps us to think about the struggles that social enterprises face in terms of two competing operational logics. For example, paying fair salaries for manual labour while still offering reasonable prices in the face of other market competitors right next door in the case of PAPE. In contrast, the notion of the "ecosystem" directs our gaze towards the local networks of actors and locally evolved specific organizational cultures. My example was Freitag, Caritas and PAPE, embedded in the strong Austrian welfare state, together with the capital city's affluent consumers demanding "ecological" and "social" products. While any form of summarizing and classifying the vast literature on social enterprises has its own difficulties, I argued that positing the "hybridity viewpoint" vice versa the "ecosystem viewpoint" is a way to get to grips with the different research interests in the literature. Both perspectives are complementary in principle, but I argue that my ethnographic-inductive approach is closer to the ecosystem viewpoint.

My research contributes in a new vein to the literature on hybridity and ecosystems in relation to social enterprising. First, because I explore the ways in which commodities might be suitable tools to study the social enterprise ecosystem. Instead of mapping the ecosystem based on national traditions, networks of organizations or administrative regions, I start with a specific social enterprise commodity that allows us to draw the connections between organizations that make up the ecosystem. Second, I suggest that recording ethnographically the judgements that the actors of the ecosystem attach to these commodities is a way to learn about the locally variable definitions and workings of social enterprising. In my case, commodities were not the main source of income for 
the social enterprise, but a means to explain their position between the capitalist corporation and the traditional welfare organization.

Nevertheless, the commodity was also focal point of ambivalence and organizational identity work for my interviewees. Ultimately my case from Vienna raises a larger research question for social enterprise scholars. What happens to the status of social enterprises when the commodity they sell is also commercialized by other types of organizations within a local marketplace? Or if asked the other way round, to what extent is the social value perception of a product within an ecosystem determined by the type of organization who sells it? Why are goods considered commercial bulk commodities or communally valuable products in the first place? How do both notions relate or mix in the case of the social enterprise commodity? By exploring ethnographically such "hybrid commodities", it is possible to get an understanding of the local definitions attached to social enterprising.

\section{References}

Alvedalen, J., \& Boschma, R. (2017). A critical review of entrepreneurial ecosystems research Towards a future research agenda. European Planning Studies, 25(6), 887903.

Battilana, J., and Lee, M. (2014). Advancing Research on Hybrid Organizing - Insights from the Study of Social Enterprises. Academy of Management Annals, 8(1), 397441.

Biggeri, M., E. Testi and M. Bellucci (2017a). Enabling Ecosystems for Social Enterprises and Social Innovation A Capability Approach Perspective, Journal of Human Development and Capabilities, 182, 299-306.

Biggeri, M., E. Testi, M. Bellucci, R. During, and T. Persson, eds. (2017b). Social Entrepreneurship in Europe: Ecosystems for Innovative and Inclusive Societies. London: Routledge.

Billis, D.(2010). Towards a Theory of Hybrid Organizations. Palgrave Macmillan 
Blim, M. (2005). The Moral Significance of Petty Capitalism. In Smart, A. and Smart, J. (Eds.), Petty capitalists and globalization: Flexibility, entrepreneurship, and economic development (pp. 253-270). New York: SUNY.

Brown, R., \& Mason, C. (2017). Looking inside the spiky bits A critical review and conceptualisation of entrepreneurial ecosystems. Small Business Economics, 49(1), 11-30.

Caritas Austria (2016). Caritas und Du. Wirkungsbericht 2015. Available at: https://www.caritas.at/aktuell/publikationen/wirkungsberichte/

Clifford, J and Marcus, G.(eds.) (1986). Writing Culture. The Poetics and Politics of Ethnography. London: University of California Press.

Cohen, B. (2006). Sustainable valley entrepreneurial ecosystems. Business Strategy and the Environment, 15(1), 1-14.

Cornforth, C. (2014). Understanding and combating mission drift in social enterprises. Social Enterprise Journal, 10(1), 3-20

Defourny, J. (2010). Concepts and realities of social enterprise: a European perspective. In A. Fayolle and H. Matlay (eds.), Handbook of Research on Social Entrepreneurship (pp. 57-87). Cheltenham: Edward Elgar Publishing.

Dey, P. and Teasdale S. (2016). The tactical mimicry of social enterprise strategies: Acting 'as if' in the everyday life of third sector organizations. Organization, 23(4), 485-504.

Doherty, B., Haugh, H., and Lyon, F. (2014). Social enterprises as hybrid organizations: A review and research agenda. International Journal of Management Review, 16(4), 417-436.

Ebrahim, A., Battilana, J., and Mair, J. (2014). The governance of social enterprises: Mission drift and accountability challenges in hybrid organizations. Research in Organizational Behaviour, 34, 81-100.

Esping-Andersen, G. (2001). Fundamentos sociales de las economías postindustriales. Barcelona: Ariel. 
European Commission. (2015). A Map of Social Enterprises and Their Ecosystems in Europe. Brussels: Directorate General for Employment, Social Affairs and Inclusion.

Frenkel, M., and Shenhav, Y. (2006). From Binarism Back to Hybridity: A Postcolonial Reading of Management and Organization Studies. Organization Studies 27(6), 85576.

Gajparia, J. (2017). Capitalising on Rapport, Emotional Labour and Colluding with the Neoliberal Academy. Women's Studies International Forum, 61, 87-92.

Gidron, B. (2017). The Dual Hybridity of Social Enterprises for Marginalized Populations, Journal of Social Entrepreneurship, 8(1), 1-13.

Gilmore, S. and Kenny, K. (2015). Work-worlds Colliding: Self-reflexivity, Power and Emotion in Organizational Ethnography. Human Relations, 68(1), 55-78.

Granovetter, M. (1985). Economic Action and Social Structure. The Problem of Embeddedness. American Journal of Sociology, 91(3), 381-510

Hazenberg, R., M. Bajwa-Patel, M. J. Roy, M. Mazzei and S. Baglioni (2016). A comparative overview of social enterprise 'ecosystems' in Scotland and England: an evolutionary perspective. International Review of Sociology, 26(2), 205-222

Hill O'Connor, C. and Baker, R. (2017). Working with and for Social Enterprises: the Role of the Volunteer Ethnographer. Social Enterprise Journal. 13 (2), 180-93.

Hustinx, L. and De Waele, E. (2015). Managing Hybridity in a Changing Welfare Mix: Everyday Practices in an Entrepreneurial Nonprofit in Belgium. Voluntas: International Journal of Voluntary and Nonprofit Organizations, 26(5), 1666-1689.

Kerlin, J. (2009). Social enterprise: a global comparison. New England: University Press of New England.

Kerlin, J. (2010). A Comparative Analysis of the Global Emergence of Social Enterprise. Voluntas: International Journal of Voluntary and Nonprofit Organizations, 21(2), 162-179. 
Kerlin, J. (2013). Defining Social Enterprise Across Different Contexts: A Conceptual Framework Based on Institutional Factors. Non-profit and Voluntary Sector Quarterly, 42(1), 84-108.

Littlewood, D, Khan, Z. (2018). Insights from a systematic review of literature on social enterprise and networks: Where, how and what next? Social Enterprise Journal, 14(4), 390-409

Marcus, G. (2001). From Rapport Under Erasure to Theaters of Complicit Reflexivity. Qualitative Inquiry, 7(4), 519-28

Martin, R.L. and Osberg, S. (2007). Social Entrepreneurship: the case for definition. Standford Social Innovation Review, Spring, 29-39.

Mauksch, S. (2016), Managing the Dance of Enchantment: an Ethnography of Social Entrepreneurship Events. Organization, 24(2), 133-153.

Mauksch, S., Dey, P., Rowe, M., and Teasdale, S. (2017). Ethnographies of social enterprise. Social Enterprise Journal, 13(2), 114-127

Mazzei, J. and O'Brien, E. (2009). You Got It, So When Do You Flaunt It?: Building Rapport, Intersectionality, and the Strategic Deployment of Gender in the Field. Journal of Contemporary Ethnography 38(3), 358-83.

Mcmullen, J. S. (2018). Organizational Hybrids as Biological Hybrids: Insights for Research on the Relationship between Social Enterprise and the Entrepreneurial Ecosystem. Journal of Business Venturing, 33(5), 575-90.

Molina, J. L., Valenzuela-García, H., Lubbers M.J., Escribano, P., and Lobato, M. (2018). The Cowl Does Make The Monk. Understanding the emergence of social entrepreneurship in times of downturn. Voluntas: International Journal of Voluntary and Nonprofit Organizations, 29(4), 725-739.

Nordstrom, S. (2015). Not So Innocent Anymore: Making Recording Devices Matter in Qualitative Interviews. Qualitative Inquiry 21(4), 388-401. 
OECD. (2016). "Building Enabling Ecosystems for Social Enterprises.” Capacity Building Seminar, 17th-18th February 2016, Brussels. Available at: http://www.oecd.org/employment/leed/socialoecd-eu-cbs.htm.

Polanyi, K. [1944]. (2001). The Great Transformation: The Political and Economic Origins of Our Time. Boston: Beacon Press.

Raišienė, A. and Urmanavičienè, A (2017). Mission Drift in a Hybrid Organization: How Can Social Business Combine its Dual Goals? Ekonomski Vjesnik, 30(2), 30110.

Roundy, P. (2017a). Hybrid organizations and the logics of entrepreneurial ecosystems. International Entrepreneurship and Management Journal, 13(4), 1221-1237.

Roundy, P. (2017b). Social Entrepreneurship and Entrepreneurial Ecosystems. International Journal of Social Economics 44(9), 1252-267.

Roy, M. J., \& Hazenberg, R. (2019). An evolutionary perspective on social entrepreneurship 'ecosystems'. In: De Bruin, A., Teasdale, S. (Eds.), A Research Agenda for Social Entrepreneurship (pp. 13-22). Cheltenham: Edward Elgar.

Roy, Michael J. \& Suzanne Grant (2019) The Contemporary Relevance of Karl Polanyi to Critical Social Enterprise Scholarship, Journal of Social Entrepreneurship, DOI: $10.1080 / 19420676.2019 .1621363$

Roy, Michael, McHugh, Neil, Huckfield, Leslie, Kay, Alan, Donaldson, Cam (2015). "The Most Supportive Environment in the World"? Tracing the Development of an Institutional ‘Ecosystem’ for Social Enterprise. Voluntas: International Journal of Voluntary and Nonprofit Organizations, 26 (3), 777-800.

Sherif, B. (2001). The Ambiguity of Boundaries in the Fieldwork Experience: Establishing Rapport and Negotiating Insider/Outsider Status. Qualitative Inquiry 7(4), 436-47.

Teasdale, S. (2010). Explaining the multifaceted nature of social enterprise: impression management as (social) entrepreneurial behaviour. Voluntary Sector Review, 1(3), 271-292. 
Teasdale, S., Lyon, F., and Baldock, R. (2013) Playing with Numbers: A Methodological Critique of the Social Enterprise Growth Myth. Journal of Social Entrepreneurship, 4(2), 113-131.

Thomsen, Bastian; Olav Muurlink, Talitha Best, (2018) The political ecology of university-based social entrepreneurship ecosystems. Journal of Enterprising Communities: People and Places in the Global Economy, 12(2), 199-219.

Young, D.R., Searing, E.A., and Brewer, C.V. (Eds.) (2017). The Social Enterprise Zoo: a Guide for Perplexed Scholars, Entrepreneurs, Philanthropists, Leaders, Investors and Policymakers. (pp. 193-212). Cheltenham: Edward Elgar 